Hildebrant Kateryna,

Ph.D (Philology), Associate Professor, Chernivtsi Institute of Trade and Economics, Kyiv National University of Trade and Economics, 7, Tsentralna square, 58002, Chernivtsi, Ukraine ORCID: 0000-0002-5806-757X Resorcher ID: 3075448

\title{
FOREIGN LANGUAGE PROFICIENCY OF UKRAINIAN STUDENTS: PROBLEMS AND SOLUTIONS
}

The article presents the current tendencies and condition of foreign language proficiency of Ukrainian higher education graduates and analyzes problems which arise in teaching English for Specific Purposes (ESP) as well as English as Medium of Instruction (EMI) in contemporary universities. Unfavorable curriculum policy, shortage of academic hours, big discrepancy in language competence of contemporary enrollees are considered as main drawbacks and factors that obstruct the Ukrainian breakthrough in ESP and EMI teaching. A compulsory B1 level of language proficiency for all entrants into higher educational establishments; increase of academic hours for foreign language learning at the expense of elective subjects; introduction of voluntary as well as compulsory (for particular students) foreign language courses during all years of study; aversion from EGP to ESP focus for EIT master's degree exam are viewed as possible solutions for improving ESP as well as EMI learning and teaching conditions in Ukraine and means to enhance the level of foreign language proficiency of Ukrainian citizens.

Key words: foreign language proficiency, English for Specific Purposes (ESP), English as Medium of Instruction (EMI), External Independent Testing (EIT), B1 (B2) level of language competence.

\section{Хільдебрандт Катерина. Іншомовні компетенції украӥнського фахівця: проблеми та вирішення.}

У статті розглянуто сучасні тенденції та стан володіння іноземною мовою випускниками украӥнських закладів вищої освіти та проаналізовано проблеми, які виникають у навчанні англійської мови професійного спрямування (АМПС) та у викладанні фахових дисциплін англійською мовою в сучасних університетах. Несприятлива політика навчальних програм, дефіцит навчальних годин, велика розбіжність у мовній підготовиі сучасних студентів вважаються основними недоліками та чинниками, щзо перешкоджають прориву Украӥни 
у навчанні АМПС. Обов'язковий рівень володіння мовою В1 для всіх вступників у ЗВО; збільшення навчальних годин для вивчення іноземних мов за рахунок факультативних предметів; впровадження добровільних, а також обов'язкових (для окремих студентів) курсів іноземних мов протягом усіх років навчання; зміна концепиії змісту СВI для вступу у магістратуру (розробка детальної специфікаиії тестів та зосередженість на АМПС) розглядаються як можливі методи підвищення рівня володіння іноземною мовою професійного спрямування випускниками украӥнських 3ВО, а також як засоби покращення умов викладання фахових дисииплін англійською мовою в Украӥні.

Ключові слова: володіння іноземною мовою, англійська мова для конкретних цілей (ESP), англійська мова як носій навчання (EMI), зовнішнє незалежне тестування (ЕIT), В1 (В2) рівень мовної компетентності.

Relevance of the research topic. Political and socio-economic changes that are taking place in Ukraine nowadays cause the formation of new economic and cultural relations with other countries, transform every person's involvement into the social production system. A major factor that underlies the changing social conditions, a prerequisite for economic, scientific and technological transformations in the country is higher education and related human resources training. Higher education and qualification is a guarantee of social well-being, a driving force for scientific investigations and innovations, as well as primary factor that estimates competitiveness of a specialist in the world labor market. Thus, the development of our country in the 21 st century is associated with the improvement of foreign languages proficiency of specialists, which will contribute to the successful integration of Ukraine into the European cultural and communicative domain.

Formulation of the problem. Significant increase in the interest towards learning a foreign language, English in particular, is caused by the expansion of international contacts and the growing integration of the country into the world community, enhanced by rapid informatization and computerization of all are as of social life: production, science, education and culture. Thus a constant search for ways to improve the system of EFL teaching has caused the necessity for implementation of innovative technologies and organization of educational activities in accordance with the targeted enhancement of students' foreign language proficiency.

Analysis of recent researches and publications. Development of foreign language competence as the formation of practical skills of oral and written communication, listening, understanding and reading; as well as the ability to apply these skills to solve communicative tasks has been investigated by miscellaneous scientists and researchers. Most of them focus on the communicative character of skills and abilities associated with the formation of foreign language competence and mention «communicative competence» as the ultimate goal for preparing competitive 
specialists (I. I. Barakhovich, N. O. Makoyed, I. A. Megalova, S. V. Kozak, A. P. Petrova, etc.). In terms of teaching English for Specific Purposes (ESP)and developing communicative competence in the sphere of professional needs, introduction of communicative approach was meant to trigger language practice in typical communicative topics relevant to a specific profession or business field (see I. Boichevska, N. Grytsiuk, T. Y. Maleeva, L. Ovcharenko, etc.). Others offer the advances of cognitive linguistics as methods to enhance Ukrainian students' language proficiency and compliment the communicative approach by means of vocabulary concept maps formation (W. Croft, S. A. Zhabotinska, M. V. Tsehelska). Strategies to augment EFL proficiency in Ukrainian higher education have been investigated by the British Council in 2017, providing the Ministry of Education and Science as well as higher educational establishments with important data and recommendations.

Setting objectives. However there still exist some serious hardships that a foreign language teacher is currently facing which should be taken into consideration when choosing improvement of foreign language proficiency as a national educational vector. In the article we'll try to analyze the current state of language proficiency and the drawbacks which don't let our country to reach the required and much desired level of language fluency.

Presenting main material. At present, English retains its dominant position in the world in business and technology spheres, and its status as a major lingua franca will hardly alter in the near future. Despite the fact that it comes third in the ranking of most spoken languages in the world after Chinese and Spanish, it's value cannot be underestimated and is expected to be further raised with the advent of new generations of technical innovations, growing Internet influence, Massive Open Online Courses (MOOCs), etc. English language as lingua franca for many businessmen becomes a medium for obtaining information and data, accessing recent achievements in different scholarly fields, maintaining international communication and building business relations. Globalization of communication in personal, academic, scholarly, economic and other areas, which will further evolve in the 21 st century, stresses the necessity to rethink the importance of improving and raising the level of language proficiency, which needs necessary reforms and innovations on the governmental level.

Despite all the enthusiasm nd interest as well as understanding of foreign language proficiency significance, the results of TEFL are far from being favorable, as the outcomes of foreign language education in Ukraine differ from expectations. According to The EF English Proficiency Index dating from October, 2018, Ukraine ranked $43^{\text {rd }}$ out of 88 world countries that participated in the survey, belonging to countries with moderate proficiency level, but very close to low proficiency countries, which start with the $45^{\text {th }}$ position in the ranking. If we compare Ukraine to its neighboring countries, we'll see that Poland $\left(13^{\text {th }}\right)$, Romania $\left(16^{\text {th }}\right)$ and Hungary $\left(21^{\text {st }}\right)$ are ranked as high proficiency countries, Belarus $\left(38^{\text {th }}\right)$ and Russia $\left(42^{\text {nd }}\right)$ share 
our moderate proficiency level, but still have better positions. Despite the fact, that Ukraine's index improved in comparison with the previous $2017^{\text {th }}$ year, when it showed a low level of language proficiency, ranking $47^{\text {th }}$ out of 80 countries (EF English Proficiency Index, 2018), the prospects for considerable improvement are still rather vague. Thus, a question arises: where and at what level do we go wrong, despite the fact that education has always been important and highly appreciated in our country?

English is chosen as primary foreign language in the majority of Ukrainian secondary schools. However it is not mandatory (there are schools with German and French as primary foreign languages), many pupils and students nowadays opt for English, taking into consideration its growing power in business cooperation and international communication. Partially to raise the expected level of language competence of Ukrainian school-leavers and to assess their knowledge, Ukrainian system of secondary education employs the External Independent Testing (EIT), analogous to ACT or SAT in the US and GSCE in the UK. Independent testing in English, as a constituent part of External Independent Testing, was developed on the basis of International English Language tests, particularly the First Certificate in English (FCE) Cambridge test (level B2 in the Common European Framework). Due to technical difficulties, Ukrainian EIT contains only the reading, writing and use of English sections as well as listening (from 2017) and omits the speaking component.

The first test, conducted in 2009, showed great discrepancy between the level of English learned at school and English required by the EIT. The low performance level of Ukrainian school graduates can partly be explained by outdated textbooks focused on the initial acquisition of English through reading texts which provide the vocabulary and grammar and not on the communicative approach, and partly on the low motivation of pupils to master a difficult discipline. These factors make teachers of English feel the necessity for updating their educational tools, so as the latter should be compatible with the new challenges of today's life.

Nevertheless, the results of EIT in English are still not so encouraging as only 0,05 per cent of the 79,594 school graduates achieved the maximum score and $12.7 \%$ did not pass it at all in 2019 as indicated by testportal.gov.ua (Rozpodil, 2019). Such poor results show that far not all of the enrollees into higher educational establishments will have the much desired B1 level of language proficiency. Thus, higher education, which is mostly focused on teaching English for Specific Purposes (ESP) and English as Medium of Instruction (EMI) to enable students to master a foreign language in accordance with the requirements of their professional field, might also fail to achieve its goals, which are rather multifarious.

The purpose of ESP for Ukrainian students is based on enabling them to make practical use of a foreign language for future professional and business needs. This TEFL activity is a training which, within the limits of the curriculum, is aimed at 
mastering a foreign language in accordance with the requirements of a certain professional field. Thus students must speak a foreign language not only as a medium of cultural interaction, but also as a means of communication within their chosen major or subject of study (to read and translate professional literature, to operate the necessary terminology, to formulate verbally business sphere exchanges). Students must reach a level of professional communication competence that allows them to actively participate in vocationally-oriented communication, confidently use a foreign language in their further professionally oriented behavior. It is aimed at gradually improving their level of professional linguistic competence, which will further help to raise their professional awareness as they start to turn to the foreign language texts not only in the course of preparation for foreign language lessons, but also to improve their professional knowledge and skills when using original business data from magazines, monographs, texts on the Internet, in the course of professional preparation.

As we can see, ESP in Ukrainian higher educational establishments pursues an ambitious and proper goal, which could have resulted in competent, highly educated and well-prepared specialists able to apply state-of-the-art solutions to contemporary challenges. But in reality, as a large number of enrollees, especially from rural areas, do not reach the level of B1 language competence, it is not uncomplicated. As students with different levels of language proficiency make up one academic group, this leads to the fact that weaker students are unable to acquire the compulsory level of language training, which ESP presupposes. They have difficulty using English in oral and written communication, experience embarrassment reading and analyzing original resources; they are unable to study professional subjects in English. At the same time, students with high foreign language proficiency levels, due to those mixed academic groups and the orientation of teaching onto the weaker student, lose their initial English language skills and, upon completion of their bachelor degree, have a lower than their entry level of foreign language competence.

Another important aspect is the curriculum policy, which, unfortunately, is far from being favorable nowadays. Despite the common idea of increased importance of language competence of Ukrainian specialists, the proportion of academic hours for ESP is declining steadily. For example, students majoring in Tourism studied ESP during three educational years in 2015 , nowadays study the same discipline for only one and a half years. Thus, as the number of hours appointed to this discipline in the curriculum decreases, so does the level of professional foreign language competence of students.

Poor results of ESP competence are even more vivid, when students want to apply for the master's degree. Since 2018 Ukrainian higher educational establishments apply External Independent Testing of language proficiency for master's enrollees, which however simplified (containing just the reading and use of foreign language 
sections), shows students' low performance. This year 32\% out of 55,186 applicants were unable to score the required number of points and were not admitted to the master's degree courses (Rezultaty, 2019). Such results can also be explained by some curriculum faults as students mostly finish learning a foreign language at the end of their second year, but have to pass the language proficiency test at the end of their fourth year. Besides, after the course of ESP they have to pass the EIT in English for General Purposes, which makes it even a more difficult and challenging task.

The recently published Project of the Ministry of Education and Science of Ukraine «Conceptual Foundations of Public Policy for the Development of English in Higher Education» stresses the necessity to increase the level of English language proficiency among graduates of higher educational institutions. Thus, graduates of Ukrainian universities should have a level of English, which allows them to fully and adequately participate in educational and professional life, both nationally and internationally (graduates of all levels must have a level of English not lower than B2). English is recognized as a key competency of a modern professional, a key tool for international communication in academic and professional life, a means to access knowledge, a condition for effective world integration and a factor of economic growth of the country. In a word, English is assumed a key tool for international communication, and a high level of English proficiency among graduates is considered to enable them to fully and effectively participate in professional and academic life (MES Project, 2019).

To ensure the effectiveness of higher education and to reach the target B2level of English proficiency among graduates, the government offers to implement a compulsory B1 level of English (German or French) proficiency for all entrants into Ukrainian higher educational establishments. Those applicants who do not correspond to the requirements will not be denied the right to participate in the higher education admission competition, but will have to complete the intensive language course to improve their proficiency level at the expense of the state budget on the basis of a higher educational establishment or by means of a distance course, developed at the request of the state, before the beginning of the school year (September 1 or October 1) to reach $\mathrm{B} 1$.

Such actions will solve lots of problems of contemporary foreign language education. First of all, they will help to fight the «language inequality» after secondary education, in particular between urban and rural entrants, and will provide access to higher education for academically capable young people who have not been able to obtain proper language education due to financial reasons. Second, these measures will enable ESP teachers to focus mostly on professional communication competence as well as required terminology and fully achieve the goals of ESP courses rather than first improving compulsory elementary grammatical or lexical awareness of poor students. 
Addressing the above mentioned curriculum problems and shortage of academic hours for ESP learning, authors of the Project recommend universities to provide additional hours for English, using 25\% of credits assigned to elective subjects. These steps will help the students to improve their level of language proficiency as the more they practice, the better the expected results will be. Besides it is suggested to include compulsory English courses into each year of the program, allocating at least $10 \%$ of the total number of hours / credits to them. Regular English courses are meant to focus on ESP rather than general English (EGP), however should be complimented by EGP courses as well. Such courses will help to overcome the «language inequality» after secondary education, besides they might fill in the gap of language training present nowadays between the times students finish their ESP course and when they have to pass the EIT exam, which will allow them to reach the desired B2 language proficiency level after graduation.

To maximize the quality of learning, it is recommended that group sizes for ESP classes do not exceed 15 students. To influence the English language content and competencies taught at the bachelor's level, the government plans to change the concept of EIT exam for master's degree, transforming it from EGP focus towards professional foreign language studied during the ESP course. This is also a good and logical initiative, however having some drawbacks, as this test will have to be adapted to different professional fields and sets of terminologies for every occupation (in the same way as ESP for law students is absolutely different from ESP for economists). Thus, the EIT exam will cease being universal and unified, but will correspond to the essence of ESP for every particular profession.

Conclusion. To sum up it is necessary to say that improving learning and teaching conditions in Ukraine at all educational levels is not an easy task to be achieved and should be viewed as a long-term challenge in the coming years. The importance of English awareness and competence is recognized at all levels and in every social sphere of life. Its value and status as lingua franca and basis for international communication has made its proficiency level improvement a nationallyfocused strategy. Thus, despite the fact that the present foreign language competence of Ukrainian students does not meet expectations according to the statistic data cited, with the help of government initiatives and their successful implementation there are good chances for positive outcomes and encouraging prospects in the future. Hopefully, Ukraine will reach the level of high foreign language proficiency countries in the coming years and will soon become a powerful member of international communication space. 


\section{REFERENCES}

1. Bolitho R., West R. (2017). The internationalization of Ukrainian universities: the English language dimension. Kyiv: British Council, 2017. 124 p.

2. Ciprianova E., Minasyan S., Ruda O. (2017). English Language Education Policies in East Central Europe: the Cases of Slovakia and Ukraine. Cross Cultural Studies: Education and Science. Volume 2. Issue I. March 2017. P. 49-66.

3. EF EPI. English First English Proficiency Index. (2018). Retrieved from : https://www.ef.co.uk/epi/regions/europe/ukraine

4. Kontseptualni zasady derzhavnoi polityky shchodorozvytku anhliiskoi movy u sferi vyshchoi osvity. Proiekt MON. (2019). [Conceptual Foundations of Public Policy for the Development of English in Higher Education. MES Project]. Retrieved from : https://www.businesslaw.org.ua/konceptualni-zasady-derjavnoipolityky-schodo-rozvytky-angliiskoi-movy/ [in Ukrainian].

5. Rezultaty VNO v mahystraturu skolko abyturyentov ne sdaly testyrovanye. (2019). [EIT Results to the Master's Degree: How Many Applicants did not Pass the Test]. Narodna Pravda. [Public Truth] 17.07.2019. Retrieved from : https://narodnapravda.ua/ru/2019/07/17/rezultaty-vno-v-magystraturu-skolko-abyturyentov-ne-sdalytestyrovanye/ [in Russian].

6. Rozpodilucha snykiv zovnishnoho nezalezhnoho otsiniuvannia 2019 roku yaki podolaly porih «sklavnesklav» $\mathrm{z}$ anhliiskoi movy za rezultata myreitynhovoho otsiniuvanniaza shkaloiu 100-200 baliv. (2019). [Distribution of participants in the external independent testing of 2019, who overcame the «passed / failed» there's hold in English, according to the rating with a scale of 100-200 points]. Retrieved from : http://testportal.gov.ua/wp-content/uploads/2019/06/Rozpodil-uchasnykiv-yakipodolaly-porig-z-angl_movy.pdf [in Ukrainian]. 